\title{
KAJIAN PERBANDINGAN INDEKS SOSIAL EKONOMI MASYARAKAT LINGKAR DAN NON LINGKAR USAHA PERTAMBANGAN NIKEL
}

\author{
${ }^{1}$ Irfan Ido \\ 'Jurusan Teknik Pertambangan Fakultas IImu dan Teknologi Kebumian \\ Universitas Halu Oleo \\ Emai: irfan.ido@uho.ac.id \\ Kota Kendari - Indonesia
}

\begin{abstract}
Mineral mining business, one of which is given to private business entities, must realize the mandate of the 1945 Constitution and the Minerba Law No. 04 of 2009 concerning the realization of people's prosperity, especially for people around the mining. The prosperity of the people is related to the social and economic welfare of the people. This paper aims to examine the socio-economic comparison of circle and non-circle communities in the nickel mining business in terms of employment opportunities, income, education and public health. This research was conducted in the Matabura Village (circle mining) and Amandete Village (non-circle mining) PT. ST Nickel Resources in Amonggedo District, Konawe Regency, Southeast Sulawesi Province. The data analysis method used is quantitative descriptive using two data analysis tools, namely: percentage analysis and social economic index analysis of the community. The conclusion of this paper is that the social economic index of the circular community is higher than the non-circular nickel mining community, but the socio-economic index of the community is equally included in the bad category.
\end{abstract}

Keywords: circle and non-circle mining; nickel; socio-economic index of the community

\begin{abstract}
Abstrak
Usaha pertambangan mineral yang salah satunya diberikan kepada badan usaha swasta mesti mewujudkan amanat dari konstitusi UUD 1945 dan regulasi UU Minerba No. 04 Tahun 2009 tentang perwujudan kemakmuran rakyat, terutama bagi masyarakat lingkar pertambangan. Kemakmuran rakyat berhubungan dengan kesejahteraan sosial ekonomi masyarakat. Tulisan ini bertujuan mengkaji perbandingan sosial ekonomi masyarakat lingkar dan non lingkar usaha pertambangan nikel dari aspek kesempatan kerja, pendapatan, pendidikan dan kesehatan masyarakat. Penelitian ini dilaksanakan di Desa Matabura (lingkar pertambangan) dan Desa Amandete (non lingkar pertambangan) PT. ST Nikel Resources di Kecamatan Amonggedo Kabupaten Konawe Propinsi Sulawesi Tenggara. Metode analisis data yang digunakan adalah deskriptif kuantitatif dengan menggunakan dua alat analisis data, yaitu: analisis persentase dan analisis indeks sosial ekonomi masyarakat. Kesimpulan tulisan ini adalah indeks sosial ekonomi masyarakat lingkar lebih tinggi dari masyarakat non lingkar pertambangan nikel, namun indeks sosial ekonomi masyarakat sama-sama termasuk dalam kategori buruk.
\end{abstract}

Kata Kunci: indeks sosial ekonomi masyarakat; lingkar dan non lingkar pertambangan; nikel

Received: DD/MM/YY; Revised: DD/MM/YY; Accepted: DD/MM/YY

Journal Publicuho is licensed under a Creative Commons Attribution 4.0 International License. 


\section{PENDAHULUAN}

Keberlangsungan kehidupan masyarakat pada suatu wilayah ditunjang oleh tersedianya sumber daya alam. Alam pada dasarnya telah menyediakan kebutuhan umat manusia baik yang bersifat biotik (hayati) maupun abiotik (non-hayati). Sumber kekayaan bumi baik biotik maupun abiotik yang dapat dimanfaatkan untuk memenuhi kebutuhan dan kesejahteraan manusia merupakan Sumber Daya Alam (SDA). Salah satu sumber daya alam adalah mineral logam nikel yang termasuk dalam golongan sumberdaya yang tidak dapat diperbaharui (Hasibuan, 2015).

Kekayaan sumber daya alam mineral nikel merupakan komoditas bernilai ekonomi tinggi yang dapat dikelola sebagai salah satu pendukung modal pembangunan termasuk sumber daya manusia. Pengelolaan mineral emas harus memperhatikan prinsip keberimbangan yaitu peningkatan nilai dengan memaksimalkan keuntungan dan hasil tetapi juga berkonsentrasi pada isu-isu lingkungan dan sosial ekonomi secara seimbang. Interaksi antara faktor sosial, ekonomi, dan lingkungan hidup sehingga dampak yang terjadi dapat diketahui sedini mungkin (Elkington, 1997; Soelistijo, 2005).

Tujuan Ekonomi dan Sosial adalah salah unsur yang harus dipenuhi dalam mewujudkan pembangunan pertambangan berkelanjutan, dimana terdapat tiga unsur penting yang harus diperhatikan agar tujuan ekonomi dan tujuan sosial dapat dicapai secara bersamaan, yaitu distribusi pendapatan, kesempatan kerja (employment), dan bantuan bersasaran (targeted assistence). Dalam konteks industri pertambangan, misalnya dengan memberikan kesempatan berusaha dan mengembangkan usaha bagi masyarakat kecil melalui pemberian pinjaman modal, penyediaan berbagai fasilitas yang mampu meningkatkan kualitas sumberdaya manusia, dan lain-lain (Pasaribu, 2011).

Dasar pengaturan dan kebijakan pengelolaan sumberdaya alam di Indonesia adalah Pasal 33 ayat (2) dan ayat (3) UUD 1945, sebagai berikut: a) Pasal 33 ayat (2): "Cabangcabang produksi yang penting bagi negara yang menguasai hajat hidup orang banyak dikuasai negara"; b) Pasal 33 ayat (3): "Bumi dan air dan kekayaan alam yang terkandung di dalamnya dikuasai oleh negara dan digunakan untuk sebesar-besar kemakmuran Masyarakat". Dalam usaha pencapaian kemakmuran dan kesejahteraan Masyarakat secara berkeadilan, maka hak penguasaan negara terhadap pengelolaan mineral emas yang berisi wewenang untuk mengatur, mengurus dan mengawasi pengelolaan atau pengusahaan pertambangan emas harus mengacu pada ketentuan Pasal 2 UU Nomor 4 Tahun 2009 tentang Pertambangan Mineral dan Batu Bara yang menyatakan bahwa pertambangan mineral dan/atau batubara dikelola berasaskan: (a) manfaat, keadilan, dan keseimbangan; (b) keberpihakan kepada kepentingan bangsa; (c) partisipatif, transparansi, dan akuntabilitas; (d) berkelanjutan dan berwawasan lingkungan (Ido Irfan, 2020). 
Journal Publicuho

ISSN 2621-1351 (online), ISSN 2685-0729 (print)

Volume 3 Number 2 (May-July), (2020) pp.193 -204

Open Access at: http://ojs.uho.ac.id/index.php/PUBLICUHO/index

Keberadaan perusahaan pertambangan berpengaruh terhadap kondisi perubahan sosial ekonomi yang sangat tergantung dengan sumber daya non tambang menjadi tergantung pada dampak positif dari keberadaan perusahaan pertambangan (Fardani, 2012). Namun, keberadaan perusahaan pertambangan tidak selamanya dapat memberikan dampak positif terhadap kondisi sosial ekonomi masyarakat. Besar kecilnya dampak sosial ekonomi masyarakat sangat bergantung pada komitmen perusahaan dalam perekrutan tenaga kerja dari masyarakat lokal dan juga tergantung pada komptensi sumber daya manusia (SDM) masyarakat lokal berupa ketrampilan dan pengetahuan tentang teknologi industri pertambangan (Pirdaus, 2016).

Masyarakat diterjamahkan menjadi dua pengertian, yaitu society dan community. Masyarakat dalam arti community terbentuk dalam suatu wadah atau tempat dengan batas-batas tertentu, maka menunjukkan bagian dari kesatuan-kesatuan masyarakat sehingga dapat pula disebut sebagai masyarakat setempat, misalnya kampung, dusun atau kota-kota kecil. Sedangkan masyarakat dalam arti society, diterjemahkan sebagai suatu badan atau kumpulan manusia yang hidup bersama sebagai anggota masyarakat. Anggota masyarakat yang bersama biasanya dianggap sebagai suatu golongan, terbagi dalam berbagai kelas menurut kedudukan dalam masyarakat itu (Abdul Syani, Hasan Shadely dalam Nasrullah, 2017).

Kondisi sosial ekonomi menurut M. Sastropradja (2000) dalam Basrowi (2010) adalah keadaan atau kedudukan seseorang dalam masyarakat sekelilingnya. Manaso (2001) dalam Basrowi (2010) juga memberikan batasan tentang kondisi sosial ekonomi yaitu, merupakan suatu kedudukan yang diatur secara sosial dan menempatkan seseorang pada posisi tertentu dalam sosial masyarakat. Sedangkan menurut Abdul Syani dalam Nasrullah 2017), sosial ekonomi masyarakat adalah kedudukan atau posisi sesorang dalam kelompok manusia yang ditentukan oleh jenis aktivitas ekonomi, pendapatan, tingkat pendidikan, usia, jenis rumah tinggal, dan kekayaan yang dimiliki. Sedangkan status sosial ekonomi seseorang dapat di ukur melalui tingkat pendidikan, pekerjaan, penghasilan, dan kekayaan yang dimilikinya. Pendidikan, pekerjaan, penghasilan dan kekayaan adalah suatu konsep yang menggambarkan suatu fenomena yang lebih nyata dibandingkan dengan konsep status sosial ekonomi (Yowaldi, 2003).

Sosial ekonomi masyarakat adalah suatu keadaan atau kedudukan yang diatur secara sosial dan menempatkan seseorang pada posisi tertentu dalam struktural sosial masyarakat. Beberapa faktor yang sering diikutsertakan dalam melihat kondisi sosial ekonomi masyarakat, antara lain: Pertama, Pendapatan Keluarga. Pendapatan nenurut Nazir (2010) merupakan suatu hasil yang diterima oleh seseorang atau rumah tangga dari berusaha atau bekerja. Jenis pekerjaan masyarakat bermacam ragam, seperti bertani, nelayan, beternak, buruh, 
serta berdagang dan juga bekerja pada sektor pemerintah dan swasta. Pendapatan rumah tangga/keluarga adalah penghasilan dari seluruh anggota rumah tangga/keluarga yang disumbangkan untuk memenuhi kebutuhan keluarga ataupun perorangan anggota rumah tangga (Sukirno, 2005)

Kedua, Pendidikan, penyelenggaraan pendidikan dilaksanakan melalui tiga jalur, yaitu jalur pendidkan formal, non formal dan informal. Jalur pendidikan formal merupakan pendidikan yang diselenggarakan di sekolah melalui kegiatan belajar mengajar secara berjenjang dan berkesinambungan. Jalur pendidikan non formal merupakan pendidikan yang diselenggarakan bagi warga masyarakat yang memerlukan layanan pendidikan yang berfungsi sebagai pengganti, penambah dan atau pelengkap pendidikan formal dalam rangka mendukung pendidikan sepanjang hayat. Sedangkan jalur pendidikan informal merupakan pendidikan yang diselenggarakan atau dilakukan oleh keluarga dan lingkungan berbentuk kegiatan belajar secara mandiri (Nasirotun, 2013).

Ketiga, Pekerjaan. Pekerjaan merupakan suatu kegiatan yang tidak bergantung pada suatu keahlian tertentu. Jadi setiap orang dimungkinkan memiliki pekerjaan namun tidak semuanya tertumpu pada satu profesi. Pekerjaan dalam arti luas adalah aktivitas utama yang dilakukan oleh manusia. Arti sempit, pekerjaan digunakan untuk suatu tugas atau kerja yang menghasilkan uang bagi seseorang. Dalam melakukan pekerjaan tidak mengandalkan keahlian dan pengetahuan khusus, pekerjaan yang dilakukan hanya digunakan untuk memenuhi kebutuhan sehari-hari, memiliki status yang rendah di masyarakat dan hanya bisa menghasilkan sedikit vang (Nasirotun, 2013).

Keempat, Kesehatan. Sehat menurut WHO (2008) dalam Chamidah (2010) adalah suatu kondisi tubuh baik fisik, mental maupun sosial tidak berada dalam kekurangan dan tidak dalam keadaan sakit maupun lemah. Kondisi tersebut dapat tercapai apabila tidak terdapat faktor internal, contohnya penyakit genetic maupun factor eksternal seperti penyakit infeksi yang dapat menyebabkan kondisi tubuh tidak berada dalam keadaan seperti yang diharapkan. Kekurangan tersebut akan menyebabkan seorang anak membutuhkan suatu bentuk perawatan kesehatan khusus.

Penelitian ini bertujuan mengkaji perbandingan sosial ekonomi masyarakat lingkar dan non lingkar usaha pertambangan nikel PT. ST Nikel Resources dari aspek kesempatan kerja, pendapatan, pendidikan dan kesehatan masyarakat.

\section{METODOLOGI}

Lokasi dari tulisan ini adalah Desa Matabura sebagai sampel desa lingkar pertambangan nikel dan Desa Amandete sebagai sampel desa non lingkar pertambangan PT. ST Nikel Resources di Kecamatan Amonggedo Kabupaten Konawe Propinsi Sulawesi Tenggara. Penentuan sampel desa lingkar maupun non lingkar usaha pertambangan nikel dilakukan secara purposive sampling dengan menggunakan pertimbangan sebagai berikut: 1). Desa 
Journal Publicuho

ISSN 2621-1351 (online), ISSN 2685-0729 (print)

Volume 3 Number 2 (May-July), (2020) pp.193 -204

Open Access at: http://ojs.uho.ac.id/index.php/PUBLICUHO/index

lingkar usaha pertambangan adalah desa yang paing dekat secara geografis dengan lokasi kegiatan operasi produksi pertambangan (site/front) atau wilayahnya dilalui oleh jalan pengangkutan material (hauling) ke terminal khusus); dan (2) Desa non lingkar tambang adalah desa yang paling jauh secara geografis dengan lokasi kegiatan operasi produksi pertambangan (site/front) dan jalan pengangkutan material (hauling) ke terminal khusus (Arifin FM, 2019).

Data mentah tulisan ini adalah data yang bersumber dari penelitian Arifin FM (2019), yang terdiri dari: a). identitas responden KRT meliputi: umur, pendidikan terakhir, dan tanggungan keluarga; b). Persepsi terhadap kondisi pendidikan; c). persepsi terhadap kondisi kesehatan; d) Persepsi terhadap kesempatan kerja; e). pendapatan

Metode analisis yang digunakan adalah deskriptif kuantitatif dengan menggunkan 2 (dua) alat analisis data dalam penelitian ini, yaitu:

a) Analisis persentase dengan persamaan $\mathbf{P}=\mathbf{f} / \mathbf{n} \mathbf{X}$ 100. Dimana: $P=$ Persen; $f=$ Skoring jumlah pernyataan jawaban responden: $n=$ Jumlah responden; dan $100=$ Bilangan tetap. Hasil analisis disajikan dalam bentuk tabel.

b) Analisis indeks sosial ekonomi masyarakat. Indeks didasarkan berdasarkan persamaan interval kelas (Sudjana, 2005): $\mathbf{I}=\mathbf{J} / \mathbf{K}$ dimana: $\mathbf{I}=$ Interval kelas; $\mathbf{J}=\mathbf{J}$ arak sebaran (nilai tertinggi kurang nilai terendah); dan K= Banyaknya kelas. Hasil interval kelas adalah 0,8. Sehingga indeks sosial ekonomi masyarakat dalam lima kategori, yaitu:

i. Nilai skor 1,00 - 1,80 kategori sangat baik (SBk),

ii. Nilai skor 1,81-2,61 kategori Baik (Bk),

iii. Nilai skor 2,62 - 3,42 kategori Kurang Baik (KBk),

iv. Nilai skor 3,43 - 4,23 kategori Buruk (Br),

v. Nilai skor 4,24 - 5,00 kategori Sangat Buruk (SBr).

Hasil analisis disajikan dalam bentuk tabel dan grafik

\section{HASIL DAN PEMBAHASAN}

Hasil dan pembahasan kajian perbandingan tingkat sosial ekonomi masyarakat lingkar dan non lingkar usaha pertambangan nike PT. ST Nikel Resources di Kecamatan Amonggedo Kabupaten Konawe Propinsi Sulawesi Tenggara dideskripsikan ke dalam 2 (dua) bagian, yaitu: (1) identitas responden, dan (2) Indeks sosial ekonomi masyarakat.

\section{Identitas responden lingkar dan non lingkar pertambangan nikel}

Identitas responden adalah identitas dari kepala kelvarga (KK) yang berdomisili di desa lingkar usaha pertambangan nikel sebanyak 63 orang dan di desa luar lingkar pertambangan nikel sebanyak 69 orang. Identitas kepala keluarga meliputi keadaan pendidikan terakhir, kelompok umur, jumlah tanggungan anggota keluarga, dan mata pencaharian. 
Keadaan tingkat pendidikan formal terakhir dari kepala kelvarga lingkar dan non lingkar pertambangan menunjukkan fenomena yang berbeda. Pada desa lingkar pertambangan nikel, jumlah KK tertinggi pada tingkat pendidikan SMP (31,75 persen). Bahkan, jumlah KK dengan tingkat pendidikan SD (28,57 persen) lebih besar dari tingkat pendidikan SMA $(22,22$ persen). Pada desa non lingkar pertambangan, jumlah tertinggi pada KK dengan tingkat pendidikan SMA (43,48 persen). Fenomena tersebut menunjukkan bahwa secara keseluruhan tingkat pendidikan KK non lingkar lebih baik daripada KK lingkar pertambangan nikel.

Kelompok umur KK dianalisis berdasarkan ketentuan dari Badan Pusat Statistik (BPS), penduduk umur 15-64 tahn dikatergorikan sebagai kelompok umur produktif, dan umur lebih dari 64 tahun sebagai kelompok tidak produktif. Hasil analisis menunjukkan bahwa kelompok umur KK baik pada desa lingkar maupun non lingkar pertambangan didominasi oleh kelompok umur produktif. Dimana, 100 persen KK lingkar tambang termasuk umur produktif sedangkan KK non lingkar hanya terdapat 3,80 persen termasuk dalam kelompok umur non produktif. Dominannya kelompok umur produktif jika dihubungkan dengan sistem ketenagakerjaan menunjukkan bahwa KK lingkar dan non lingkar pertambangan termasuk dalam angkatan kerja. Dari kelompok umur, KK lingkar lebih produktif dibandingkan dengan KK non lingkar pertambangan.

Tabel 1. Perbandingan Identitas Responden Kepala Keluarga Lingkar dan Non Lingkar Usaha Pertambangan Nikel, 2019

\begin{tabular}{lcccc}
\hline \multirow{2}{*}{$\begin{array}{l}\text { Identitas Responden } \\
\text { A. Pendidikan Formal Terakhir }\end{array}$} & \multicolumn{2}{c}{$\begin{array}{c}\text { Lingkar Usaha } \\
\text { Pertambangan }\end{array}$} & \multicolumn{2}{c}{$\begin{array}{c}\text { Non Lingkar Usaha } \\
\text { Pertambangan }\end{array}$} \\
\cline { 2 - 6 } & Orang & Persen & Orang & Persen \\
\hline a) Tidak Tamat SD (0 tahun) & 1 & 1,59 & 1 & 1,45 \\
b) SD (6 tahun) & 18 & 28,57 & 12 & 17,39 \\
c) SMP (9 tahun) & 20 & 31,75 & 23 & 33,33 \\
d) SMA (12 tahun) & 14 & 22,22 & 30 & 43,48 \\
e) PT (>12 tahun) & 10 & 15,87 & 3 & 4,35 \\
\hline B. Kelompok Umur & & & & \\
a) 15-64 tahun (produktif) & 63 & 100,00 & 64 & 96,20 \\
b) >64 tahun (tidak produktif) & 0 & 0,00 & 5 & 3,80 \\
\hline C. Tanggungan Keluarga & & & & \\
a) Kecil (<4 orang) & 11 & 17,46 & 28 & 40,58 \\
b) Sedang (4-6 orang) & 52 & 82,54 & 41 & 59,42 \\
c) Besar (>6 orang) & 0 & 0,00 & 0 & 0,00 \\
\hline D. Pekerjaan & & & & \\
a) Petani & 21 & 33,33 & 48 & 69,57 \\
b) Buruh & 22 & 34,92 & 7 & 10,14 \\
c) Pekerja Tambang & 0 & 0,00 & 0 & 0,00 \\
d) Wirausaha & 7 & 11,11 & 6 & 8,70 \\
e) Wiraswasta & 6 & 9,52 & 4 & 5,80 \\
f) PNS & 7 & 11,11 & 4 & 5,80 \\
\hline SUmyyyyyyy
\end{tabular}

Sumber: Hasil analisis data mentah dari Fajin FM (2019) 
Journal Publicuho

ISSN 2621-1351 (online), ISSN 2685-0729 (print)

Volume 3 Number 2 (May-July), (2020) pp.193 -204

Open Access at: http://ojs.uho.ac.id/index.php/PUBLICUHO/index

Tanggungan keluarga adalah anggota keluarga yang tinggal satu rumah, jika jumlah keluarga yang semakin banyak besar menyebabkan kepala keluarga memerlukan tambahan pengeluaran atau kebutuhan penghasilan yang lebih tinggi untuk membiayai kehidupan keluarganya. Hasil penelitian menunjukkan bahwa KK lingkar maupun non lingkar pertambangan nikel tidak memiliki tanggungan keluarga dalam kategori besar. KK lingkar pertambangan dominan memiliki tanggungan keluarga dalam kategori sedang. Sementara itu, KK non lingkar pertambangan dominan memiliki kategori keluarga sedang dan kecil. Hal tersebut menunjukkan bahwa pengeluaran kehidupan keluarga lebih besar KK lingkar pertambangan dibandingkan dengan KK non lingkar pertambangan nikel.

Pekerjaan merupakan suatu kegiatan yang tidak bergantung pada suatu keahlian tertentu. Jadi setiap orang dimungkinkan memiliki pekerjaan namun tidak semuanya tertumpu pada satu profesi (Efendi, 2017). Hasil analisis menunjukkan bahwa jumlah KK lingkar tambang terbesar adalah bekerja sebagai buruh (34,92 persen), selanjuntya bekerja sebagai petani (33,33 persen). Tidak ada satupun KK yang bekerja di pertambangan. Keberadaan ketenagakerjaan usaha pertambangan nikel ternyata tidak memberikan akses kepada masyarakat lingkar tambang, justru mendorong terjadinya perubahan jenis pekerjaan dari petani menjadi buruh. Keberadaan usaha pertambangan nikel justru menghilangkan kepemilikan asset lahan sehingga petani terpaksa memutuskan beralih bekerja di sektor non pertanian menjadi buruh (Davis, 2003; Khaafidh dan Poerwono, 2013; Sigit 1998 dalam Haris Prabowo, 2011). Kondisi ini merupakan fenomena pencucian sumber daya manusia (SDA) pertanian di perdesaan akibat adanya kegiatan pertambangan. Pada KK non lingkar pertambangan juga tidak terdapat KK yang memiliki pekerjaan di kegiatan pertambangan nikel. Akan tetapi, fenomena pencucian SDM pertanian tidak terjadi dimana pekerjaan KK sebagai petani sangat dominan (69,57 persen).

\section{Indeks Sosial Ekonomi Masyarakat Lingkar dan Non Lingkar Pertambangan Nikel}

Indeks sosial ekonomi masyarakat tersebut akan memberikan gambaran tentang dampak dari kegiatan pertambangan nikel apakah telah memberikan dampak positif atau tidak terhadap kondisi sosial ekonomi masyarakat. Kegiatan usaha pertambangan nikel wajib memenuhi amanat Pasal 2 UU Minerba 04 Tahun 2009 dan Pasal 33 Ayat 3 UUD 1945 yang mengamanatkan bahwa pengelolaan sumber daya alam (SDA) termasuk nikel mesti mewujudkan kemakmuran rakyat, khususnya masyarakat lingkar tambang. Realisi perwujudan kemakmuran rakyat adalah jika kegiatan usaha pertambangan nikel dapat mendorong keadaan sosial ekonomi masyarakat dalam kategori baik dan sangat baik.

Hasil dan pembahasan mengenai indeks sosial ekonomi masyarakat lingkar dan non lingkar pertambangan nikel yang akan dibahas meliputi 4 aspek, yaitu: pendidikan keluarga, kesehatan keluarga, kesempatan kerja keluarga dan pendapatan keluarga. Indeks sosial 
ekonomi masyarakat merupakan hasil tabulasi dan analisis yang bersumber dari data persepsi dan pendapatan masyarakat. Keadaan Indeks sosial ekonomi masyarakat lingkar dan non lingkar pertambangan nikel disajikan pada Gambar 1 dan Tabel 2.

Hasil analisis menunjukkan bahwa (Gambar 1), nilai indeks sosial sosial ekonomi masyarakat baik lingkar adalah 2,05, sedangkan masyarakat non lingkar pertambangan nikel PT. ST Nikel Resources adalah 1,87. Terlihat nilai indeks sosial ekonomi masyarakat lingkar lebih tinggi dari masyarakat non lingkar pertambangan nikel, namun nilai indeks sosial ekonomi masyarakat sama-sama termasuk dalam kategori buruk. Indeks sosial ekonomi dalam kategori buruk menunjukkan sebuah kenyataan bahwa keberadan kegiatan pertambangan nikel PT. ST Nikel Resources di Kecamatan Amonggedo Kabupaten Konawe Propinsi Sulawesi Tenggara belum mewujudkan amanat dari konstitusi UUD 1945 dan regulasi UU Minerba No. 04 Tahun 2009 tentang perwujudan kemakmuran rakyat dalam pengelolaan sumber daya alam, terutama bagi masyarakat lingkar pertambangan.

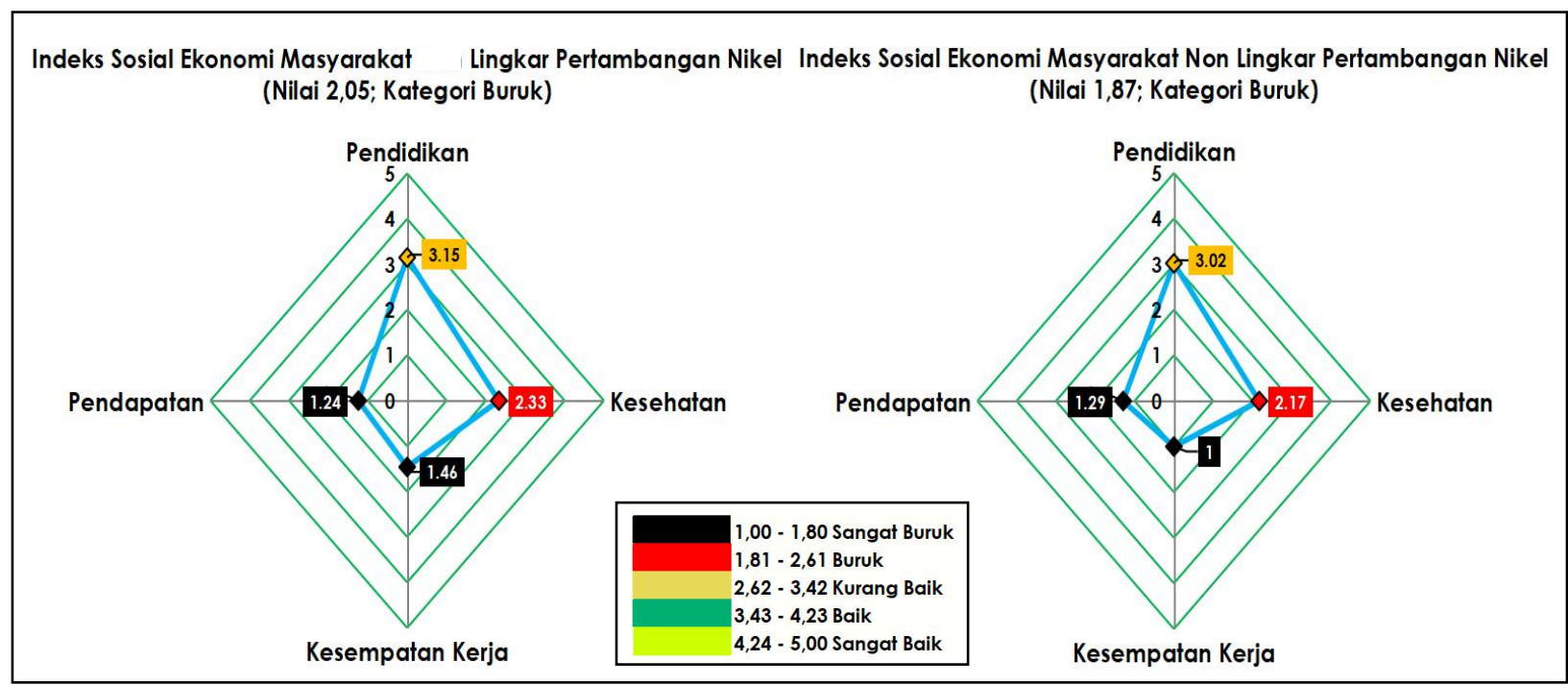

Gambar 1. Perbandingan Indeks Sosial Ekonomi Masyarakat Desa Lingkar dan Non Lingkar Pertambangan Nikel, 2019

Kategori buruk indeks sosial ekonomi masyarakat lingkar dan non lingkar pertambangan nikel dipengaruhi oleh nilai indeks variabel sosial ekonomi, yaitu: indeks kesempatan kerja masyarakat yang sangat buruk, indeks pendapatan masyarakat yang sangat buruk, indeks kesehatan masyarakat yang buruk, dan indeks pendidikan masyarakat yang kurang balik, yang disajikan pada Tabel 2.

Indeks kesempatan kerja masyarakat lingkar pertambangan $(1,46)$ lebih tinggi dari masyarakat non lingkar pertambangan $(1,00)$, namun keduanya dalam kategori sangat buruk. Indeks kesempatan kerja sangat buruk dinyatakan oleh 68,25 persen masyarakat lingkar pertambangan dan seluruh masyarakat (100,00 persen) non lingkar pertambangan. Hal ini menunjukkan bahwa realisasi kinerja perusahaan pertambangan nikel dalam memberikan/membuka kesempatan kerja masyarakat berupa: perekrutan masyarakat lokal 
Journal Publicuho

ISSN 2621-1351 (online), ISSN 2685-0729 (print)

sebagai tenaga kerja pertambangan dan terbukanya peluang usaha non pertambangan masyarakat lokal sangat buruk. Perusahaan pertambangan semestinya memprioritaskan kesempatan kerja yang besar kepada masyarakat lingkar pertambangan sesuai dengan amanat konstitusi dan komitmen pada saat sosialisasi dan konsultasi konsultasi publik pengurusan perizinan. Namun pada kenyataannya, amanat konstitusi dan komitmen tersebut tidak terealisasi. Padahal, masyarakat lingkar pertambangan telah melepaskan aset lahan pertaniannya (konversi lahan) yang masuk dalam wilayah izin usaha pertambangan (WIUP) yang berimplikasi kepada kehilangan pekerjaan (petani) dan lainnya terpaksa memutuskan untuk beralih menjadi buruh karena tidak terakomodir sebagai tenaga kerja pada perusahaan pertambangan. Masyarakat lingkar pertambangan juga telah memberikan izin sosial operasi produksi (the social licence to operate) yang menjadi pertimbangan utama dalam penerbitan IUP operasi produksi perusahaan. Pemberian izin sosial tersebut dengan harapan operasi produksi pertambangan dapat memberikan kesempatan menjadi tenaga kerja dan membuka peluang usaha non pertambangan yang dapat menjamin keberlanjutan pendapatan keluarga untuk dapat membiayai kebutuhan anggota keluarga. Kesempatan kerja yang minim dan tidak terbukanya lapangan usaha lainnya akibat kegiatan pertambangan tersebut berimplikasi terhadap buruknya pendapatan keluarga masyarakat lingkar pertambangan.

Hasil analisis pendapatan menunjukkan fakta yang menarik bahwa indeks pendapatan masyarakat lingkar pertambangan $(1,24)$ lebih rendah dari masyarakat non lingkar pertambangan $(1,29)$ yang termasuk dalam kategori sangat buruk. Indeks pendapatan masyarakat lingkar pertambangan sangat buruk karena 92,06 persen masyarakat pendapatannya dalam kategori buruk dan sangat buruk. Tidak ada masyarakat yang pendapatannya dalam kategori sangat baik. Pendapatan masyarakat non lingkar pertambangan juga sangat buruk terbentuk dari 92,76 persen masyarakat pendapatannya dalam kategori buruk dan sangat buruk namun terdapat 2,90 persen masyarakat yang pendapatannya dalam kategori sangat baik. Hal ini mengindikasikan bahwa pendapatan masyarakat lingkar pertambangan justru lebih buruk setelah adanya kegiatan pertambangan nikel di wilayahnya. Kategori pendapatan sangat buruk tentu saja berimplikasi terhadap menurunnya kemampuan keluarga untuk membiayai kebutuhan tanggungan kelaurga yang besaran tanggungan keluarga dominan dalam kategori sedang (4-6 orang). Menurunnya kemampuan keluarga selain membiayai kebutuhan pangan, juga tidak kalah pentingnya dalam membiayai kebutuhan pendidikan dan biaya kesehatan kelvarga, dan pada akhirnya berimplikasi pada kurang baiknya kondisi pendidikan dan buruknya kesehatan tanggungan keluarga. 
Tabel 2. Persentase Tingkat Sosial Ekonomi Masyarakat Desa Lingkar dan Non Lingkar Pertambangan Nikel, 2019

\begin{tabular}{|c|c|c|c|c|c|}
\hline & \multirow{2}{*}{ Tingkat Sosial Ekonomi } & \multicolumn{2}{|c|}{$\begin{array}{l}\text { Lingkar Usaha } \\
\text { Pertambangan }\end{array}$} & \multicolumn{2}{|c|}{$\begin{array}{c}\text { Non Lingkar Usaha } \\
\text { Pertambangan }\end{array}$} \\
\hline & & Orang & Persen & Orang & Persen \\
\hline \multicolumn{6}{|c|}{ A. Kesempatan Kerja Keluarga } \\
\hline$>$ & Sangat Buruk $(1,00-1,80)$ & 43 & 68,25 & 69 & 100,00 \\
\hline$>$ & Buruk $\quad(1,81-2,61)$ & 20 & 31,75 & 0 & 0,00 \\
\hline$>$ & Kurang Baik $(2,62-3,42)$ & 0 & 0,00 & 0 & 0,00 \\
\hline$>$ & Baik $\quad(3,43-4,23)$ & 0 & 0,00 & 0 & 0,00 \\
\hline$>$ & Sangat Baik $\quad(4,24-5,00)$ & 0 & 0,00 & 0 & 0,00 \\
\hline \multicolumn{6}{|c|}{ B. Pendapatan Kelurga (Rp. 000 pertahun) } \\
\hline & Sangat Buruk $(1,00-1,80)$ & 54 & 85,71 & 60 & 86,96 \\
\hline & $(1,81-2,61)$ & 4 & 6,35 & 4 & 5,80 \\
\hline & Kurang Baik $(2,62-3,42)$ & 4 & 6,35 & 3 & 4,35 \\
\hline$>$ & $(3,43-4,23)$ & 1 & 1,59 & 0 & 0,00 \\
\hline$>$ & Sangat Baik $(4,24-5,00)$ & 0 & 0,00 & 2 & 2,90 \\
\hline \multicolumn{6}{|c|}{ C. Pendidikan Keluarga } \\
\hline & Sangat Buruk $(1,00-1,80)$ & 1 & 1,59 & 7 & 10,14 \\
\hline & $(1,81-2,61)$ & 8 & 12,70 & 1 & 1,45 \\
\hline & Kurang Baik $\quad(2,62-3,42)$ & 33 & 52,38 & 43 & 62,32 \\
\hline$>$ & $(3,43-4,23)$ & 19 & 30,16 & 18 & 26,09 \\
\hline & Sangat Baik $\quad(4,24-5,00)$ & 2 & 3,17 & 0 & 0,00 \\
\hline \multicolumn{6}{|c|}{ D. Kesehatan keluarga } \\
\hline & Sangat Buruk $(1,00-1,80)$ & 6 & 9,52 & 8 & 11,59 \\
\hline & $(1,81-2,61)$ & 37 & 58,73 & 49 & 71,01 \\
\hline & Kurang Baik $(2,62-3,42)$ & 20 & 31,75 & 12 & 17,39 \\
\hline & $(3,43-4,23)$ & 0 & 0,00 & 0 & 0,00 \\
\hline & Sangat Baik $\quad(4,24-5,00)$ & 0 & 0,00 & 0 & 0,00 \\
\hline
\end{tabular}

Sumber: Hasil analisis data mentah dari Fajrin FM (2019)

Indeks pendidikan masyarakat lingkar pertambangan $(3,15)$ lebih tinggi dari masyarakat non lingkar pertambangan $(3,02)$, namun keduanya dalam kategori kurang baik. Indeks pendidikan kurang baik dinyatakan oleh 52,38 persen masyarakat lingkar pertambangan dan 62,38 persen masyarakat non lingkar pertambangan. Hal ini menunjukkan bahwa realisasi kinerja perusahaan pertambangan nikel terhadap perbaikan kondisi pendidikan masyarakat berupa: pengembangan sarana pendidikan dan kemampuan pemenuhan kebutuhan biaya 


\section{Journal Publicuho}

ISSN 2621-1351 (online), ISSN 2685-0729 (print)

sekolah masih sangat minim. Sarana pendidikan yang ada merupakan pembangunan yang dilakukan oleh pemerintah daerah, belum ada tambahan sarana prasarana pendidikan termasuk bantuan beasiswa dari perusahaan pertambangan. Kemampuan masyarakat untuk membiayai sekolah tanggungan keluarga kurang baik juga disebabkan oleh sangat buruknya pendapatan masyarakat baik lingkar maupun non lingkar pertambangan.

Indeks kesehatan masyarakat lingkar pertambangan $(2,33)$ lebih tinggi dari masyarakat non lingkar pertambangan $(2,7)$, namun keduanya dalam kategori buruk. Indeks pendidikan buruk dinyatakan oleh 58,73 persen masyarakat lingkar pertambangan dan 71,01 persen masyarakat non lingkar pertambangan. Hal ini menunjukkan bahwa realisasi kinerja perusahaan pertambangan nikel terhadap perbaikan kondisi kesehatan masyarakat berupa: pengembangan sarana kesehatan dan kemampuan pemenuhan kebutuhan biaya kesehatan adalah buruk. Kondisi tersebut sama dengan kinerja perusahaan terhadap pedidikan masyarakat, dimana sarana kesehatan yang dibangun oleh pemerintah daerah, belum ada tambahan sarana prasarana pendidikan dari perusahaan pertambangan nikel. Begitupun kemampuan masyarakat untuk biaya kesehatan berobat ke puskesmas dan/atau rumah sakit dalam kategori buruk yang disebabkan oleh sangat buruknya pendapatan masyarakat baik lingkar maupun non lingkar pertambangan.

\section{KESIMPULAN}

Kesimpulan tulisan ini adalah indeks sosial ekonomi masyarakat lingkar lebih tinggi dari masyarakat non lingkar pertambangan nikel, namun indeks sosial ekonomi masyarakat sama-sama termasuk dalam kategori buruk. Indeks tersebut dipengaruhi oleh nilai indeks variabel sosial ekonomi masyarakat, sebagai berikut:

a) Indeks kesempatan kerja masyarakat lingkar pertambangan $(1,46)$ lebih tinggi dari masyarakat non lingkar pertambangan $(1,00)$, namun keduanya dalam kategori sangat buruk.

b) Indeks pendapatan masyarakat lingkar pertambangan $(1,24)$ lebih rendah dari masyarakat non lingkar pertambangan $(1,29)$ yang termasuk dalam kategori sangat buruk.

c) Indeks pendidikan masyarakat lingkar pertambangan $(3,15)$ lebih tinggi dari masyarakat non lingkar pertambangan $(3,02)$, namun keduanya dalam kategori kurang baik.

d) Indeks kesehatan masyarakat lingkar pertambangan $(2,33)$ lebih tinggi dari masyarakat non lingkar pertambangan $(2,7)$, namun keduanya dalam kategori buruk. 


\section{DAFTAR PUSTAKA}

Arifin FM, 2019. Kondisi sosial ekonomi masyarakat desa lingkar dan non lingkar pertambangan nikel di kecamatan amonggedo kabupaten konawe provinsi sulawesi tenggara (studi kasus desa matabura dan desa amandete). Skripsi. Jurusan Teknik Pertambangan. FITK UHO.

Basrowi dan Juariah, S., 2010, Analisis Kondisi Sosial ekonomi dan Tingkat Pendidikan Masyarakat Desa Srigading, Kecamatan Labuhan Maringgai, Kabupaten Lampung Timur, Universitas Lampung, Lampung.

Chamidah, A. N., 2010, Pendidikan Inklusif untuk Anak dengan Kebutuhan Kesehatan Khusus, Jurnal Pendidikan Khusus. Vol. 7 (2).

Davis, J. R. 2003. The Rural Non-Farm Economy, Livelihoods and Their Diversification: Issues and Options. NRI Report No: 2753.

Elkington, J. 1997 Cannibal with Forks, the Tripple Bottom Line of Twentieth Century Business, Capstone Publishing Ltd, London.

Ido Irfan, 2020. Model Pengelolaan Tambang Berkelanjutan dalam Upaya Penguatan Sosial dan Ekonomi Masyarakat Perdesaan pada Kegiatan Tambang Emas di Kabupaten Bombana. Disertasi. Prodi llmu Pertanian PPs UHO.

Hasibuan, N. M., 2014, Analisis Dampak Keberadaan PT. Agincourt Resources Terhadap Tingkat Kesejahteraan Masyarakat Batang Toru Kabupaten Tapanuli Selatan, Univeritas Sumatera Utara, Medan.

Khaafidh, M dan Poerwono, D (2013). Faktor-faktor yang Mempengaruhi Keputusan Tenaga Kerja untuk Berkerja di Kegiatan Pertanian (Studi Kasus : Kabupaten Rembang). Fakultas Ekonomika dan Bisnis Universitas Diponegoro, Semarang

Nasirotun, S., 2013, Pengaruh Kondisi Sosial Ekonomi dan Pendidikan Orang Tua Terhadap Motivasi Melanjutkan Pendidikan ke Perguruan Tinggi pada Siswa, IKIP Veteran Semarang, Semarang.

Nasrullah, Rulli. 2017. Media Sosial : Perspektif Komunikasi, Budaya, dan Sosioteknologi. Bandung:Remaja Rosdakarya.

Nazir, 2010, Analisis Determinan Pendapatan Pedagang Kaki Lima di Kabupaten Aceh Utara, Universitas Sumatera Utara, Medan.

Pasaribu, 2011. Dampak atas keberadaan Pertambangan Emas PT. Agincourt Resources terhadap Sosial Ekonomi Masyarakat di Kecamatan Batang TorU Kabupaten Tapanuli $\begin{array}{llll}\text { Selatan.diakses } & \text { pada } & 10 / 05 / 2020 & \text { pukul }\end{array}$ http://repository.usu.ac.id/handle/123456789/22264.

Pirdaus, M., 2016, Strategi Pengembangan Sumber Daya Manusia pada Kelompok Usaha batu Akik Sisik Naga di Kecamatan Baraka Kabupaten Enrekang, Universitas Negeri Makassar, Makassar.

Republik Indonesia, 2009, Undang-Undang Nomor 4 Tahun 2009 Tentang Pertambangan Mineral dan Batubara, Sekretariat Kabinet Republik Indonesia, jakarta.

Prabowo, Haris dan Poerwono Dwi setia. Analisis Faktor Yang Mempengaruhi Keputusan Tenaga Kerja Desa Untuk Bekerja di Kegiatan Non Pertanian 104 (Studi Kasus: Kabupaten Pekalongan). 2011. Jurnal Universitas Diponegoro.

Sudjana. (2005). Metode Statistika. Bandung: Tarsito

Soelistijo, Ukar W. 2005. Pengembangan Sumberdaya Mineral Dan Energi sebagai Sarana Penggerak Mula Dalam Pengembangan Wilayah Orasi Pengekuhan Ahli Peneliti Utama Bidang Ekonomi Mineral, Energi Dan Pengembangan Wilayah, Departemen Energi Dan Sumberdaya Mineral.

Sukirno, Sadono. 2005. Mikro Ekonomi, Teori Pengantar. Penerbit PT. Raja Grafindo Persada, Jakarta

Sugiyono, 2010, Memahami Penelitian Kualitatif, Alfabeta, Jakarta.

Yowaldi, 2013, Jurnal Penelitian, IdentifikasiAktivitas Sosial Ekonomi Masyarakat Akibat Keberadaan Industri di kecamatan Kaliwungu, Universitas Semarang, Semarang. 